Journal of Science Education Research

Journal homepage: www.journal.uny.ac.id/jser

\title{
JSER
}

\section{DEVELOPING A VIRTUAL LABORATORY FOR THE MATERIALS ON OPTICS TO INCREASE JUNIOR HIGH SCHOOL STUDENTS' LEARNING OUTCOMES}

\author{
Neni Yulianita ${ }^{1}$, Tri Jalmo ${ }^{2}$, and Abdurrahman ${ }^{2}$ \\ ${ }_{1}^{1}$ Teaching at Pugung State Junior High School 1, Tanggamus, Lampung \\ ${ }^{2}$ A Lecturer at Natural Science Education Master Program, Lampung University \\ Corresponding Author. Email: neniyulianita81@ gmail.co.id
}

\section{Keywords:}

virtual laboratory, learning outcomes, material on optics

\begin{abstract}
This study aims to improve the concept mastery of students on optics through the development of a virtual laboratory. This research and development consisted of three stages, namely the preliminary study, the design of the virtual laboratory, and the virtual laboratory testing/implementation. The validity of the virtual laboratory is based on the results of the expert validation on the aspects of suitability of the contents and construction. The study used mixed-methods with exploratory sequential design in the form of Nonequivalent Control Group Design. The samples were taken using purposive sampling technique. This study involved 25 students of class VIII 1 as the experimental group and 25 students of class VIII 3 as the control group at Pugung Junior High School 1. The data were collected using observation, questionnaires and tests, and interviews. Then the data were analyzed using independent sample t-test and homogeneity test to see the learning effectiveness of the two sample groups. The results show that the practicality of learning using the developed virtual laboratory has been very successful and received good responses from the students. The effectiveness of the virtual laboratory can be seen from the $\mathrm{N}$-gain of 0.44 (moderate level). Therefore, virtual laboratories can be used as teaching tools that are able to contribute positively to increase students' learning outcomes.
\end{abstract}

C2018 JSER. Yogyakarta State University

\section{INTRODUCTION}

Science and technology have brought humans towards more advanced civilizations. Mastery of science and technology is an indicator of the acceleration and growth of a nation (Dharma, 2012). Science is related to ways to find out about nature systematically, so science is not only the mastery of a collection of knowledge in the form of facts, concepts, or principles but also a process of discovery (Takari, 2010). Science learning among students should learn not about not only the products but also the aspects of the process, attitude, and technology so that students can really understand the science as a whole. Technology is a tool to facilitate humans in fulfilling the needs by considering the carrying capacity of natural resources, and science is required to explain natural phenomena (Wisudawati and Sulistyowati, 2014). The development of science and technology increasingly encourages efforts in renewing and utilizing technology results in the learning process (Arsyad, 2014). Wasis (2013) states that $21^{\text {st }}$ century education not only pays attention to core subjects as happened in the previous century but also gives emphasis on life skills, learning and thinking skills, and information and communication technology literacy (ICT literacy).

Science learning is still a problem in several countries. The Ministry of Education and Culture (2015) states that from the TIMSS (Trends in International Mathematics and Science Study) and PISA (Programme for International Student Assessment) survey results, in 2011 TIMSS for 
grade 8 attended by 42 countries, in the field of science, more than 20 participating countries were still below the TIMSS standard value of 500 . Meanwhile, from the 2012 PISA results followed by 65 countries, 40 countries were still below the PISA standard value of 500 . The results of the PISA assessment for Indonesian students in science are very alarming. According to the OECD (Organization for Economic Cooperation and Development) Report, the 2012 PISA results on the science rankings show that the average science score of Indonesian students was 382, placing Indonesia in the bottom two, 64 out of 65 PISA participating countries (OECD, 2013). Based on these data, it appears that Indonesian students have very low skills in science, ranked the lowest 2 compared to other countries. The low quality of science learning in Indonesia is due to the ineffectiveness of the learning process, where learning is still teacher centered. Students are not accustomed to develop their thinking potential (Takari, 2010). Liliasari and Tawil (2013) also say that many teachers do a lecturing method because they consider science to be a collection of knowledge that must be transferred to the students.

Virtual laboratories are laboratories that can simulate a real laboratory environment and are defined as a learning environment where students transform their theoretical knowledge into practical knowledge by conducting experiments (Tatli and Ayas, 2013). The facts in the field show among 15 junior high school teachers from public and private schools in Lampung Province, $66.7 \%$ of schools had science laboratories, and only $33.3 \%$ of teachers used laboratories in science learning for the materials on optics. This is due to limited laboratory equipment for the materials on optics. Based on the results of the preliminary study, $36.4 \%$ of schools do not have laboratory equipment for the materials on optics. Abstract science concepts require practicum in the laboratories where the teacher is in charge of assisting the students to learn, guiding the students to do exercises and operate the theories in the classrooms, and guiding the students to conduct experiments in the laboratories (Arsyad, 2014).
Therefore, to manage the limitations of laboratory equipment, practicum activities in natural science learning can be performed through virtual laboratories.

Some research results discuss the use of virtual laboratories in several teaching-learning processes and levels of education. The overall results of these studies reveal that learning using virtual laboratories significantly influences the abilities of students and ultimately improves the quality of learning. Therefore, a deeper analysis is needed to determine the effects of virtual laboratory-based natural science learning on improving students' learning outcomes. Based on the background above, this study aims to develop a virtual laboratory to improve students' learning outcomes.

\section{METHOD}

This was research and development (Sugiyono, 2014). The development of the virtual laboratory in this research adapted from Borg and Gall (1983) was divided into 3 (three) stages, namely: (1) conducting preliminary study, (2) designing the virtual laboratory/product, and (3) testing the effectiveness of the virtual laboratory. The research method used was mixed-method with an experimental sequential design in the form of Nonequivalent Control Group Design (table 1). The study was conducted at Pugung 1 State Junior High School in May-June 2018. The population of this study was all eighth grade students. The samples, class VIII 1 as the experimental group and class VIII 3 as the control group, were taken by purposive sampling technique. In the preliminary study, literature review was conducted to obtain the data used as a theoretical foundation and strengthen arguments about the product developed and field study was performed by distributing questionnaires on the need analysis of the virtual laboratory. The development stage covered designing, product, expert validation, and limited testing. It produced the design of the learning tool.

Table 1. Research Design

\begin{tabular}{cccc}
\hline Groups & Pre-test & Action & Post-test \\
\hline Experimental & $\mathrm{O}_{1}$ & $\mathrm{X}$ & $\mathrm{O}_{2}$ \\
Control & $\mathrm{O}_{3}$ & - & $\mathrm{O}_{4}$ \\
\hline
\end{tabular}


In the implementation phase, the extensive testing was carried out among the control group. In the learning process, the control group was given a textbook provided by the school. Meanwhile, the experimental group used the virtual laboratory in the learning process. Then the two groups were given the same test/questions. The data in this study were both quantitative and qualitative data. The quantitative data were obtained from the pretest and post-test scores. The qualitative data in the form of students' responses were obtained from the questionnaires and interviews about learning using the virtual laboratory. The students' learning outcomes were reviewed based on Normalized gain or $\mathrm{N}$-gain using the following Hake formula (1999):

$$
\mathrm{g}=\left(\mathrm{S}_{\mathrm{pos}}-\mathrm{S}_{\mathrm{pre}}\right) /\left(\mathrm{S}_{\mathrm{max}}-\mathrm{S}_{\mathrm{pre}}\right)
$$

Notes:

$\mathrm{g}=$ Average $N$-gain,

$\mathrm{S}_{\mathrm{pos}}=$ Average post-test score,

$\mathrm{S}_{\mathrm{pre}}=$ Average pre-test score,

$\mathrm{S}_{\max }=$ Maximum score

$N$-gain criteria: High if $\mathrm{g}>0,7$, Moderate if $0,7>\mathrm{g}>0,3$, and Low if $\mathrm{g}<0,3$.

The data on students' learning outcomes were collected by tests. The qualitative data in the form of students' responses were obtained through questionnaires, and the success in the administration of learning using the virtual laboratory was seen from the observation sheets and interviews with students after the learning process. The quantitative data were in the form of pre-test and post-test scores, and the $\mathrm{N}$-gain values in the experimental and control groups were analyzed using the t-test. The two mean similarity test and two mean difference test were employed to test the hypotheses. The qualitative data were analyzed descriptively.

\section{RESULT}

The design of the developed virtual laboratory consists of 1) Title Page and 2) Main Menu (Figure 1).

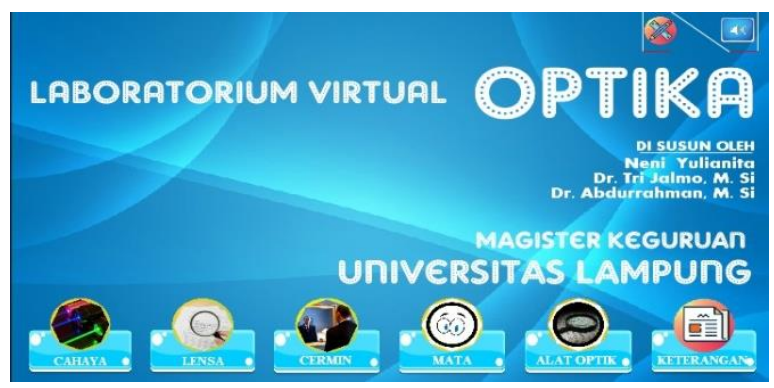

Figure 1. The Title Page and Main Menu of the Virtual Laboratory
The validity of the developed virtual laboratory was evaluated based on the assessment of 3 experts (table 2).

Table 2. The results of the expert validation on the developed virtual laboratory

\begin{tabular}{|l|l|c|c|}
\hline No & \multicolumn{1}{|c|}{$\begin{array}{c}\text { Aspects } \\
\text { Assessed }\end{array}$} & $\begin{array}{c}\text { Percentage } \\
(\%)\end{array}$ & Categories \\
\hline 1. & $\begin{array}{l}\text { Suitability of } \\
\text { contents }\end{array}$ & $85.7 \%$ & $\begin{array}{l}\text { Very } \\
\text { Valid }\end{array}$ \\
\hline 2. & Construction & $86.7 \%$ & $\begin{array}{c}\text { Very } \\
\text { Valid }\end{array}$ \\
\hline
\end{tabular}

Suggestions for improvement from the experts for the suitability of the virtual laboratory contents are the addition of the virtual laboratory manual instructions and clearer simulations so that the contents are easily understood by the students. Simulations that represent laboratory experiments should be made as real as possible, and the computer simulations that enable important functions of laboratory experiments are to be carried out on a computer. These are in accordance with Harm's opinion (Gunawan, 2011) stating that virtual -lab presents a set of experimental devices that can be operated in the form of simulations. The results of a research conducted by Tuysuz (2010) also claim that simulations found in virtual laboratories provide a positive contribution in increasing students' motivation in the subjects learned. Based on the limited testing, from the teacher assessment on the suitability of contents, it can be seen that the suitability of the contents of the virtual laboratory and the construction are in the very high category. Thus, it can be said that the virtual laboratory is generally suitable to be utilized in the teaching-learning process (table 3 ).

Table 3. The results of teacher assessments of the developed virtual laboratory $(n=5)$

\begin{tabular}{|c|l|c|c|}
\hline No & $\begin{array}{l}\text { Aspects } \\
\text { Assessed }\end{array}$ & Percentage & Categories \\
\hline 1. & $\begin{array}{l}\text { Suitabilit } \\
\text { y of } \\
\text { contents }\end{array}$ & $91.4 \%$ & Very high \\
\hline 2. & $\begin{array}{l}\text { Construct } \\
\text { ion }\end{array}$ & $88 \%$ & Very high \\
\hline
\end{tabular}

The results of the data analyses show that the virtual laboratory affects the students' learning outcomes on optics.

Table 4 shows that the control group has the $\mathrm{N}$-gain value $=0.30$, while the experimental group has the $\mathrm{N}$-gain value of 0.44 . Based on the data from the experimental group, the scientific literacy of the students significantly increases. 
Table 4. The results of the t-test on scientific literacy

\begin{tabular}{|c|c|c|c|c|c|}
\hline No & Groups & Pre-tess & Post-test & n- Gain & t-test \\
\hline & & $\mathrm{X} \pm \mathrm{Sd}$ & $\mathrm{X} \pm \mathrm{Sd}$ & $\pm \mathrm{Sd}$ & \\
\hline 1. & Control & $36.80 \pm 13,52$ & $56.32 \pm 13.21$ & $0.30 \pm 0.16$ & .000 \\
\hline 2. & Experimental & $37.60 \pm 13,86$ & $64.80 \pm 9.73$ & $0.44 \pm 0.08$ & .000 \\
\hline
\end{tabular}

Furthermore, the results of the t-test analyses show that that the value of sig is $(0.00)<005$ which means that $\mathrm{H}_{\mathrm{o}}$ is rejected. Therefore, there is a significant difference in $\mathrm{N}$-Gain between the control group and the experimental group.

From the results of the research and data analyses where the t-test results show significant difference, it can be seen that the virtual laboratory effectively increases students' scientific literacy. This increase occurs because the virtual laboratory is used to guide the students to do the science process, which is by conducting experimental activities using simulation. Based on the results of data analyses, there is an increase in students' scientific literacy seen from the differences in the $\mathrm{N}$-gain values. The increase in literacy in the experimental group is because this group uses the validated virtual and learns using computers with adobe flash player CS 6 application so that the experimental group students gain new experiences in learning. Virtual laboratories are a series of laboratory instruments in the form of interactive multimedia-based computer software that is operated by computers and can simulate activities in the laboratories as if the user is in an actual laboratory (Sutrisno, 2012). Potential virtual laboratories give significant improvements and more effective learning experiences. The laboratories encourage students to think critically, creatively, and analytically. The other supporting factors are the high response of the virtual laboratory users, the good implementation of learning with virtual laboratories, and high student activities.

After the N-gain was obtained, the normality test was conducted to see whether the data are normally distributed or not. Normality test is a prerequisite for conducting t-test. The results of the normality test using the KolmogorovSmirnov method indicate that the learning outcomes are normally distributed with the value of Asymp.Sig (2-tailed) of more than 0.05, which is 0.277 for the control group and 0.320 for the experimental group. After the normally distributed data were obtained, a homogeneity test was conducted to see the similarity of variance between the two groups. The homogeneity test results show that the significance value of the similarity test is 0 . 850 which is greater than 0.05 , so it can be concluded that the two groups have the same variant.

From the results of data analyses using the t-test, the value of Asymp.Sig (2-tailed) is 0.837 or more than 0.05 . Thus, it can be concluded that there is a significant $\mathrm{N}$-gain difference between the control group and the experimental group. The average $\mathrm{N}$-gain for the experimental group is higher than the control group. An increase in students' learning outcomes after learning using the virtual laboratory is shown in Figure 2.

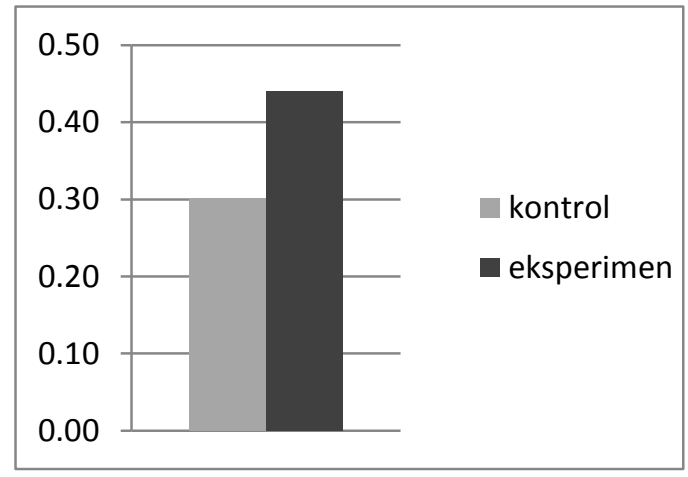

Figure 2. An increase in students' learning outcomes

Table 5. The results of the students' response to the virtual laboratory

\begin{tabular}{|c|l|c|c|}
\hline No. & \multicolumn{1}{|c|}{ Aspects Assessed } & Percentage \% & Criteria \\
\hline 1. & Learning motivation & 84.61 & Very high \\
\hline 2. & $\begin{array}{l}\text { Interest in learning using } \\
\text { the virtual laboratory }\end{array}$ & 95.19 & Very high \\
\hline 3. & Growing confidence & 92.30 & Very high \\
\hline \multicolumn{2}{r|}{ Average } & 90.7 & Very high \\
\hline
\end{tabular}


While learning using the virtual laboratory, the students look more motivated, more active in learning, and more confident. In general, students' responses to the virtual laboratory are very high (Table 3 ).

The results of the interviews show that almost all students enjoy the learning process using the virtual laboratory. The results of the interviews and students' responses indicate that most students feel happy in learning using the virtual laboratory and motivated to learn the materials on optics. They also think the virtual laboratory can increase motivation and confidence. In addition to time management issue, the number of concepts taught also becomes the factor affecting the teachinglearning process using the virtual laboratory.

\section{CONCLUSION}

Based on the results and discussion, it can be concluded that virtual laboratories are suitable to use in the teaching-learning process and effectively improve students' learning outcomes.

\section{REFERENCES}

Arsyad, Azhar, M.A. 2014. Media Pembelajaran. PT Raja Grafindo Persada. Jakarta

Aryana, I. P. (2007). "Pengembangan Peta Pikiran untuk Peningkatan Kecakapan." Berpikir Kreatif Siswa". Jurnal Pendidikan dan Pengajaran. 40, (3), 670-. 693.

Borg, Walter R. \& Gall, Meredith D. 1983. Education Research: An Introduction (4th ed). Longman Inc. New York

Dharma, Agus. 2012. Peran Sains dan Teknologi Dalam Percepatan Pembangunan, Jurnal. Available at staffsite.gunadarma.ac.id/agus_dh/. Accessed on January 12, 2016.

Gunawan. 2011. Pengembangan Model Virtual Laboratory Fisika Modern untuk Meningkatkan Keterampilan Generik Sains dan Disposisi Berfikir Kritis Calon Guru. Jakarta. UPI. Journal. http://journal.um.ac.id/index.php/pendidikan -dan-pembelajaran/article/view/3867. Accessed on October 15, 2018

Hake, Richard R. 2002. Analyzing Change/Gain Scores. (Online). Available at (http://www. physics. indiana. edu/ sdi/Analyzing Change-Gain.pdf), accessed on November 16, 2015.
Kemdikbud. 2015. Materi Pelatihan Guru Implementasi Kurikulum 2013. Badan Pengembangan SDM Pendidikan dan Kebudayaan. Penjamin Mutu Pendidikan Kemdikbud.

Organisation for Economic Cooperation and Development (OECD)2016. Snapshot of performance in mathematics, reading and science. (Online). Available at (http://www.oecd.org/pisa/-PISA-2015results-snapshot-Volume-I-ENG.pdf), accessed on December 30, 2016

Kemdikbud. 2015. Materi Pelatihan Guru Implementasi Kurikulum 2013 Badan Pengembangan SDM Pendidikan dan Kebudayaan. Penjamin Mutu Pendidikan Kemdikbud

Liliasari dan Tanwil, Muh.2013. Berpikir Kompleks dan Implementasinya dalam Pembelajaran IPA. Badan Penerbit Universitas Negeri Makassar. Makassar

Organisation for Economic Cooperation and Development (OECD). 2013. Chapter 3 of the Publication "PISA 2003 Assesment of framework - mathematics, Reading, Science and problem solving knowledge and skills. [Online]. Available at: http://www.oecd.org /dataoecd/38/29/33707226. pdf. Accessed on November 11, 2015.

Sugiyono.2014. Metode Penelitian Pendidikan Pendekatan Kuantitatif, Kualitatif, dan R \& D.Alfabeta. Bandung

Takari, Enjah R. 2010. Model Kooperatif Ilmu Pengetahuan Alam. Penerbit GENESINDO. Bandung

Tatli, Zeynep \& Ayas, Alipasa., 2013. Journal. Effect of Virtal Chemistry Laboratory on Students' Achievement. Educational Technology \& Society. 16 (1). 159-150. Accessed on August 10, 2015.

Wasis. 2013. Merenungkan Kembali Hasil Pembelajaran Sains. Seminar Nasional FMIPA UNDIKSHA III. Universitas Negeri Surabaya.Surabaya.wasisfaa@yahoo.com

Sutrisno.2011. Pengantar Pembelajaran Inovatif Berbasis Teknologi Informasi \& Komunikasi. GP Press. Jakarta.

Tatli, Zeynep \& Ayas, Alipasa., 2013. Journal. Effect of Virtal Chemistry Laboratory on Students' Achievement. Educational Technology \& Society. 16 (1). 159-150. Accessed on August 10, 2015

Wisudawati, A.W., \& Sulistiyowati, E. 2014. Metodologi Pembelajaran IPA. BumiAksara. Yogyakarta 